\title{
Between Individual and Collective Action: Citizen Participation and Public Oversight in Mexico's Oportunidades Programme
}

\author{
Felipe Hevia de la Jara'
}

\begin{abstract}
1 Introduction
Programmes against poverty implemented in Mexico over the last 30 years have become experimental laboratories for citizen participation in social policy: food programmes in the 1970s and 1980s, implemented through the establishment of committees for rural supply; Solidarity National Programme (Pronasol) in the 1990s, also implemented by establishing thousands of solidarity committees; and the PROGRESA/Oportunidades programme, implemented between the end of last century and early years of the current one. All those programmes have different institutional designs in order to boost (but often in fact limiting and guiding) the forms and capacities of people's real participation in the design, operation, societal control and evaluation of social programmes (Isunza and Hevia 2006).
\end{abstract}

This article focuses specifically on the PROGRESA/ Oportunidades programme as it is the most extensive poverty alleviation programme currently in operation in Mexico, with five million beneficiary families, a ten-year history and an institutional design that broke with the participatory paradigm of former projects.

The implementation of the Education, Health and Nutrition Program (PROGRESA) in 1997 broke the traditional way that poverty alleviation programmes had been run up until that time. The principal change was that the family became the target of the programme, rather than the community. For this reason, programme design promoted a direct relationship between government and families, instead of relying on existing organisations, such as peasants' cooperatives, rural workers' unions and community associations. This design was to suppress any kind of societal intermediation. But there was another reason for this: those who formulated the programme shared the view that those organisations were committed to old corporatist, authoritarian and clientelistic practices. Therefore, the exclusion of community organisations and the strengthening of direct links with the beneficiaries aimed to prevent the reproduction of the old distortions of social policies in Mexico: corruption, authoritarian corporatism and political clientelism.

\begin{abstract}
Nevertheless, as I point out in this article, the inadequate design of the mechanisms intended to empower the beneficiaries to oversee the programme, as well as the Mexican government's inability to set mechanisms of direct communication with the millions of covered families, rendered the intermediation of local institutions indispensable. Such intermediaries were thus granted new and powerful instruments of control and consequently enabled the continuation of authoritarian and clientelistic practices.
\end{abstract}

In addition, there was a lack of effort on the part of social actors to control, investigate and denounce these distorted relations. This is probably due to the fact that, on the one hand, many of those community and rural workers' organisations are engaged in the same authoritarian and self-serving practices in dealing with their own low-class constituency, and on the other hand, nongovernmental organisations (NGOs) and civil organisations for citizen rights were little concerned 
with overseeing the programme, as many of their own members were involved in its management.

In fact, the election of Vicente Fox and the widening of political powers brought to PROGRESA a new stream of policymakers (Fox 1992) that the author calls the 'civic stream' (corriente civica). Their main characteristics are deep linkage with civil organisations and non-partisanship. Besides changing the name of the programme from PROGRESA to Oportunidades, this stream introduced important moves towards new kinds of relations with beneficiaries and civil organisations. They gave priority to direct relations with families by means of campaigns for public information and oversight, and so aimed to prevent abusive political use of the programme. Hence, dissemination of information and policies for citizens' active participation were boosted, and mechanisms were set for preventing the political use of the programme during elections.

These changes, however, did not affect the mechanisms for verifying conditionalities, which were thus maintained in the hands of local authorities and intermediaries. As a consequence, changes had little efficacy in restraining authoritarian practices. Although the 'civic stream' shared a negative view of intermediation by traditional rural workers' organisations and was aware of the hazards of adding new intermediaries, they were also unable to design, until 2005, regular forums of cooperation and information (rather than deliberative participation) for civil organisations interested in defending and ensuring the rights of the poorest portion of the population.

This incapability was closely related to the little concern these organisations actually showed for the programme. Civic associations did not push or fight either for public overseeing or for stopping abuses of power at either the federal or the local level. As the 'civic stream' was taking part in the government, they were confident that it would be enough to ensure that things were correctly done.

From this, it can be learned that effective prevention, control and punishment of abuse of authority requires an institutional structure capable of embodying both direct and collective actions to oversee the programme's performance. Finally, it demonstrates that there must be collective actors enabled to and concerned with overseeing public policy if we want to prevent abuses of power.

This article is divided in three parts. In the first part, the structure of participation in the PROGRESA/ Oportunidades programme is surveyed, the main characteristic of which is the search for direct relations between the beneficiaries and the programme, avoiding the intermediation of community and rural workers' organisations, as they were found to be authoritarian, corporatist and corrupted. The second part describes the position taken by social actors in such a restrictive context for participation, and offers some interpretations on why civil organisations showed so little concern in effectively overseeing the programme. Finally, a series of lessons taken from this case is presented in order to strengthen the structure of citizens' participation to counterbalance political power.

\section{PROGRESA/Oportunidades programme}

The Programa de Desarrollo Humano Oportunidades (Programme for Human Development Opportunities, PO) was founded in 1997 and first called PROGRESA It has been maintained throughout three different presidential administrations ${ }^{1}$ and has grown year after year both in budget and coverage. ${ }^{2}$ The $\mathrm{PO}$ is a conditional cash transfer programme and is guided towards the improvement of human capital, generation of capabilities and breaking the circle of poverty spread from one generation to another. It combines the identification and targeting of beneficiaries, direct cash transfers to the families (particularly the women) and optimisation of the use of institutional resources in education, nutrition and healthcare by means of conditionalities or beneficiaries' co-responsibilities.

Accordingly, the heads of households (usually women) only receive economic support if they attend monthly workshops on healthcare and consult the general practitioner at least once a year. Scholarships are granted to children and adolescents from primary (third year) to junior high school, provided they are enrolled in the schools and regularly attend the classes. Adolescents who continue their studies, attending either high school or a college, are granted cash aid for selfmaintenance or productive projects. Two other financial aids have been recently set up: a financial aid to third age members of the programme and one as an 'energy subsidy'. 
The amount of money that each family receives depends on the official confirmation that the coresponsibilities have been accomplished. Those in charge of issuing this confirmation are the doctors and nurses of the healthcare centres, and public school teachers.

The programme was born at a particular juncture: the Mexican politics and economy crisis triggered in 1994. This included unpopularity of the ending government of president Carlos Salinas, political disarticulation of the Revolutionary Institutional Party (Partido Revolucionario Institucional, PRI) and the Zapatista rebellion in the south of the country. All these factors and deep ideological differences between Salinas' social policymakers and those of his successor Ernesto Zedillo contributed to the end of the National Solidarity Programme (Pronasol). This social programme became symbolic of the Salinas administration and was then stigmatised as an instrument exploited for political gains. Without making any considerable progress against poverty, it was considered to have reproduced the same clientelistic and corporatist practices as the worst times of the post-revolutionary period - by means of a secondary, abusive political network set up throughout the whole country (namely, the Solidarity Committees) and a presidential system with no counterbalances.

The functioning of Pronasol rested on Solidarity Committees in every region of the country. These committees were in charge of establishing priority for the many actions to be carried out, their public control (through the board of public oversight) and allocating labour and financial resources for the project's execution. Nonetheless, like the traditional PRI corporations, this network of committees worked as a secondary source of political power, rewarding those loyal to the president with extra resources, while punishing anti-incumbent positions. Therefore, these resources were distributed according to partisan interests rather than technical criteria, thus making little impact on poverty (Cornelius et al. 1994).

As Pronasol had been plainly used for political purposes and had little effect on poverty alleviation, PROGRESA's policy designers and managers intended to distinguish it from Pronasol. Such a distinction was easily noticed in the programme's central features (targeting, centralised management, expenditures directed specifically to rural zones, an emphasis on human capital development), as well as in the relation between government and beneficiaries.

The main changes included targeting families rather than the communities, and the limiting of any kind of intermediation between federal government and benefited families. The central argument was that cash transfers made directly to families would not require any local intermediation structure (Levy and Rodríguez 2004). In this sense, local intermediation structures (whether governmental or not) in rural zones were viewed as retrograde, unprepared, corporatist, corrupt and clientelistic. Many municipal mayors had not even completed primary school education and intermediation institutions were inclined toward authoritarian corporatism and other corrupt practices. As such, a variety of mechanisms were adopted to prevent local intermediation and promote transparency in the programme's operations.

The localities to receive the programme's resources were selected by the central offices in Mexico City according to census data, without the participation either of government representatives (state governors, elected representatives or municipal presidents) or civil organisations.

As for the programme's admittance process, private companies had been in charge of accepting and evaluating application forms up until 2002. From this year on, the process of targeting depended on the programme's National Coordination, again without the participation of any civil organisation or association.

Families were selected according to a mathematical scoring system. Public financial institutions were hired to deliver the aid, preventing municipal or state authorities from having any part in the transfers. Finally, a system of state liaisons, dependent of National Coordination and called coordinaciones estatales, was developed to bring the operation 'closer' to the population. Municipal spheres were deliberately left out of all these processes - municipal administrations had hardly any attribution or role in PROGRESA - and the same happened to traditional communitarian, rural workers' and political organisations. The idea was to eliminate any kind of intermediation from the operational processes.

The selection of beneficiaries, localities and families depended and still depends exclusively on the 
National Coordination. There is no possibility of an organisation asking for 'benefit shares' in favour of its members, nor can professors or doctors have any role in deciding which families are truly poor and which 'do not need' the aid.

Communities and their organisations only had a small part in designing the programme: a community assembly. Once the beneficiary families have been selected, a community assembly should detect possible mistakes concerning the inclusion or exclusion of families (those included but 'without real need' for the aid, as well as those left out but truly in need). Nevertheless, independent evaluations have shown the inefficiency of this process year after year (Adato 2004).

In short, grounded reasons - such as the prevention of authoritarian and mass patronage practices - led to the design of a system that could operate without intermediation. The central government was supposed to hold direct relations with the benefited families. Nonetheless, this design required direct communication with the beneficiaries for its operation to be effective.

The question of how the families could be listened to did not seem difficult: various mechanisms to attend to citizens had been established at state level though in a disorderly manner. These mechanisms were only organised into a unified system in 2003, when the Citizen Complaints System (Sistema de Atención Ciudadana) began to strengthen. In this way, each family had the possibility (at least in theory) of communicating with the programme by letter or telephone, without intermediation.

But things become more complex when the objective is to speak directly with beneficiaries. The question is: how to reach each of the thousands of towns in Mexico's most remote areas - the places where the majority of the programme's beneficiaries are concentrated? In a country where there are no mailing addresses in smaller localities (addresses are simply listed as 'general delivery'); where the postal service generally functions poorly; where there was no official photo ID until 1990 (when the IFE, Elections Federal Institute, issued voter registration cards); where there is no banking network, etc. How can these families be informed of the payment date? How can they be informed that they have not made good on their co-responsibilities and so will receive less money? How can an accurate survey of beneficiaries be maintained? In the face of the State's incapacity to communicate directly with the beneficiaries, the only possible solution was to create a transmission belt information system, which, in other words, meant constructing new intermediaries.

In 1999 PROGRESA had to incorporate two figures which did not depend directly on the centralised National Coordination: a municipal liaison (enlace municipal) and a communitarian promoter (promotora). The former was a municipal employee paid by city hall, responsible for advising title holders of payment dates as well as providing security to its actual delivery. The communitarian sponsor, on the other hand, was a 'representative' of the beneficiaries whose principal responsibility was to transmit information from the liaison to the rest of the programme's beneficiaries, as well as ensuring that the beneficiaries spend the financial aid that they receive appropriately (González and Escobar 2002).

Later, with the change of name from PROGRESA to Oportunidades in 2002, when the programme's coverage began to increase, the liaisons' and the communitarian sponsors' responsibilities expanded as they collaborated with the programme's operators to update survey data and conduct other important procedures.

Due to the evident influence acquired by these agents, the programme attempted year by year to limit their intermediation power. The requisites for the position of municipal liaison increased (e.g. specifying that they be appointed by a local town council and prohibiting leaders of political parties) and, from 2002 on, individual sponsors were replaced by Committees of Community Development (CPC) which were made up of three (and later four) beneficiaries elected by their peers.

This change sought to limit the power that the municipal liaisons were acquiring as intermediaries between the programme and the beneficiary families. It also hoped to strengthen the programme's information system and monitor the title-holders themselves. In this way, the actions and functions of these committees continued to be defined from the National Coordination, and ended up as platforms for the representation of the programme vis-à-vis beneficiaries, rather than vice versa. Consequently, their principal actions continue 
to be governmental functions executed towards the beneficiaries: to inform title-holders of payment dates, to organise co-responsibilities and to ensure that the transfers are put to good use, among others (Oportunidades 2006).

These changes, however, could not put an end to authoritarian corporatism and the culture of political clientelism at the local level, as many of the institutional intermediaries became political operators. The position of municipal liaison turned out to be useful for political ascension: many municipal mayors constructed their political capital around PROGRESA/Oportunidades. CPC members also kept the same practices that the $\mathrm{PO}$ had so eagerly intended to avoid, such as solicitation of benefit shares, political proselytism, improper behaviour towards opposition, etc. In fact, most of the complaints concerning 'proselytism' involved CPC members and municipal liaisons/authorities, reinforcing the association of collective action with political clientelism. ${ }^{4}$

In addition, the control system for co-responsibilities, essential to a conditional cash transfer programme, was of great advantage to these intermediaries. Those in charge of confirming the fulfilment of obligations in fact control the amount of money that goes to each family. If a family is reported to have failed in their co-responsibilities, there are quite concrete consequences - they will receive less money. State actors (especially those from public healthcare) and institutional intermediaries can take great advantage of this control instrument, for it allows every sort of abusive power practice, with a low possibility of punishment.

As a consequence, many of the programme's beneficiaries are often given a kind of a second class citizenship, being forced to carry out community work, such as sweeping the streets or healthcare posts, or to give part of the money they receive to the authorities as a condition to keep receiving it. If they denounce such practices, they risk losing their benefits altogether, given the way in which the control of coresponsibilities works. What can the poor do in these cases? How can they prevent such situations?

It is of vital importance to ensure efficient mechanisms of accountability and public overseeing. The institutional design of the Oportunidades allows for only one possibility: the system of citizen complaints and suggestions, which in the end leaves individual programme beneficiaries to face a government officer. ${ }^{5}$ With the exception of an annual meeting with civil organisations, collective action does not have regular and institutional instances of denouncement and negotiation with the authorities.

There were no changes in the form of relation with NGOs and civic society until 2005, eight years after the programme was founded. Then the 'civic stream', in one of their last innovations, created a Programme of Incentive for Civil Society Organisations, the basic tasks of which are to provide information to these organisations, develop experiments of social supervision concerning the programme results and hold an annual meeting for accountability of the actions performed during the year. However, the small number of organisations inscribed in the programme (only 58 in 2006) and the little concern they have shown in taking part in the control of the PO points out the limitations of this mechanism of public oversight.

This brings us to the central question: Is it possible to set up an efficient system of direct participation capable of promoting the public overseeing of public programmes, without intermediation between families and government? The Oportunidades case shows that it is not possible, either when the state lacks capacity to communicate with beneficiaries, or when there is a wide set of political institutions and state agencies controlling the beneficiaries themselves. It also shows that placing extreme limits on intermediation also reduces the possibility of denouncing and punishing abuses of power, because collective action cannot find an effective institutional platform for the exercise of societal control over policy and politics. Finally, as will be seen in the following section, it shows that, no matter how stable the mechanisms related to social organisations for the poor are, the quality of the collective actors who take part in the process is still crucial in determining its success or failure. If they are not concerned or capable, the programme's structure by itself is not sufficient to ensure that it functions soundly.

\section{Social actors: civic stream and lack of dialogue}

The public targeted by PROGRESA/Oportunidades programme are people in the most precarious social conditions, unprotected and vulnerable. Its beneficiaries are the poorest of the poor. The fact that it targets mainly the population of rural zones 
and with women acting as family representatives results in an even greater inequality of power between the beneficiaries and the government. How can an indigenous woman who does not speak Spanish denounce the doctor who asks her to wash his clothes; the municipal authority who forces her to attend party meetings or who threatens to cut off her benefits if she does not vote in accordance with this or that party?

As mentioned above, participation mechanisms were designed in a way that does not empower the beneficiaries to solve this kind of problem. They are forced to confront a huge government structure as individuals, and this article has shown that sometimes participation platforms are not the solution, but rather a part of the problem. In addition, the society-state relationship in rural Mexico has been historically associated with public authorities' abusive practices. Therefore, the woman as described above is ill-prepared to defend herself from 'authorities'.

That is why collective action is of fundamental importance for the enhancement of beneficiaries' protection capacities and reducing unbalances of power. Representation institutions were set and strengthened in Mexico during the twentieth century, especially in rural areas, such as the councils of ejidatarios and communal assemblies, which still function considerably well. In addition, rural workers' leagues and confederations that played an important role in balancing the post-revolutionary regimen are still influential in agrarian policies, as can be seen from their participation in subsidiary rural programmes like Alianza para el Campo. Several organisations, both civil and governmental, are active in many intensely impoverished regions reached by the programme, and they work with the same women that match the programmes beneficiary profile. However, neither traditional organisations, such as the communal assemblies and councils of ejidatarios, nor the rural workers' associations seem to be concerned with overseeing or taking part in the programme.

The same may be said of the social organisations. The Programme of Incentive for Social Organisations, for instance, counted a total of 58 organisations inscribed in 2006. Nevertheless, no more than five joint projects were conducted between 2005 and 2006 (Hevia 2007). In short, although they are better provided with capacities to defend the public of
Oportunidades, the organised actors do not seem to be pressing for the improvement of participatory spaces within the programme.

To better explain this situation, this article goes on to analyse the two opposite phenomena. First, generally speaking, rural workers' organisations with a more traditional profile do not interact with the programme at the local level because they consider it a programme for women, and one which, in addition, provides only small amounts for each family (notwithstanding the fact that the total sum is quite considerable). These factors weaken the interest of rural workers and communal authorities in using their time and influence to fight abuses of power. In these cases, they only act when the problem appears to be very serious. ${ }^{6}$ They are usually more interested in programmes that can bring resources in the form of fees or commissions to cover administration costs. As the PROGRESA/Oportunidades programme pays small financial amounts to the families, there is greater interest in other programmes that involve more resources to fewer beneficiaries. Such is the case, for instance, with programmes that provide assistance to rural workers. Moreover such organisations consider the assistance paid by the programme as minor aid to the families. The fact that it is a programme for women shows the little symbolic importance these authorities attribute to them. But the political operators that intend to manipulate the programme understand very well what these beneficiaries represent: political clienteles with little public oversight and, therefore, a breeding ground for a generation of political leaders for this kind of voter. Designers and operators seem to be right in their diagnosis concerning corruption and authoritarian corporatism. As specialised literature has stressed, collective actors do not necessarily represent civic virtues; nor do their practices always favour the strengthening of democracy (Dagnino et al. 2006; Gurza Lavalle 2003).

However this does not explain why NGOs and civic organisations show little interest in overseeing the programme, and why, when they do so, they focus exclusively on watching the potential use of the programme for political and electoral purposes. ${ }^{7}$ This seemingly lack of attention may have much to do with the presence of 'civic stream' within the programme. Rogelio Gómez-Hermosillo, the national coordinator of the programme, was the ex-director of the Civic Alliance, which is one of the organisations fighting 
hard for fair elections. This gave the NGOs confidence that Gómez-Hermosillo and his team would bring transparency and non-authoritarian dynamics into the programme, eliminating and fighting political and electoral uses of the programme. Indeed, his administration was receptive and proactive in respect to the organisations. However, those organisations were unable to take advantage of the opportunity, partly because they were at a stage of relatively low enthusiasm compared with the euphoria that precedes political transition (Olvera 2001).

Therefore, the Mexican collective actors that could have watched over the programme were then either more part of the problem than the solution, or they did not have capabilities for defending more general public aspirations, but only particular ones. Traditional or rural workers' organisations were little concerned with a programme for women that provided small financial aid to families, while the fact that the 'civic stream' was within the programme staff appeared to guarantee its transparency and good administration. These factors did not contribute to improvements in participation and public oversight beyond the delivery of information, and the system of citizen complaints held very limited possibilities for fighting abusive political practices.

\section{Conclusions}

According to what has been shown in the Mexican case, the prevention of abuses of authority and the effectiveness of systems of public oversight require an institutional design that admits both direct action on the part of each family, but also collective action as a means to communicate with the programme. If any of these possibilities are blocked, the capacity for public overseeing on behalf of the impoverished people will be reduced.

If the possibilities for individual action are obstructed, organisations may be strengthened but, in turn, the authoritarian control over low-class constituencies will also be strengthened. The monopoly of representation can be very inefficient in overseeing public policy, as seen in the post-revolutionary times of the PRI. If the spaces of institutional power and the forms of representation are not well designed, they will not be able to contribute to the transparency or efficiency of public policy.

But the complete exclusion of any kind of intermediation is equally inefficient, as it limits the real power of negotiation that collective actions can have, and puts the victim alone to face the whole government structure. On the other hand, if the structure does not explicitly specify a capable agency for oversight, taking into consideration collective action and allowing for the adequate representation of interests, authoritarian practices will return disguised as informal operators or institutional intermediaries whose practices are even more difficult to control and whose manoeuvring may have even more harmful consequences for the poorest portion of the population.

In other words, there is no contradiction between forums for direct, individual action and those for collective action regarding the oversight of and participation in public policy. Given the large portion of the population that benefits from Oportunidades, it is necessary to develop and strengthen forums of direct action in order to have an efficient system of information for and from the population. It is important that the population is well informed and has access to a strong, efficient system for filing complaints and suggestions. But it is also necessary to strengthen the collective action of the beneficiaries themselves so that they can be, first of all, citizen counterbalances within the programme. This is the way to reduce the inequalities of political power and improve the programme's efficiency.

But the structure is only one side of the coin. As the Mexican case demonstrates, without concerned and independent collective actors, with effective resources for action and oversight, such spheres may become vacuous mechanisms of ornamental participation. The constant flow of information to the title-holders is still one of the most effective instruments to prevent abuses of power. Nonetheless, it is also necessary to strengthen the independent forums of collective action, both on the part of the title-holders themselves and on the part of civil society. With the election of Felipe Calderón to the Mexican presidency in 2006 - amidst doubts about his legitimacy - the 'civic stream' left the programme, while a confessed party activist was installed in the national coordination for the first time since its foundation in 1997. It is of fundamental importance, therefore, that the social organisations watch over the programme in order to hinder the return of clientelistic and corporatist mechanisms that had been previously overcome, specifically at the federal level. 
In summary, the Mexican experiment shows that two factors - a structure that combines collective and individual actions as well as concerned and independent social actors - seem to be essential to

\section{Notes}

* I would like to thank specially Adrián Gurza Lavalle and Peter Houtzager for their contribution and insights to developing the argument in this article. I want to thank too Yuriko Takahashi, Monika Dowbor, Graziela Castello, Liza Serfim and Samana Vergara-Lope for their comments and contributions. Any omissions or mistakes are mine.

1 The programme started in the government of Ernesto Zedillo from the Partido Revolucionario Institucional (PRI) and has gone on throughout the governments of Vicente Fox and Felipe Calderón, both from the Partido Acción Nacional (PAN).

2 The PO has grown year after year both in coverage and budget. It started in 1997 with 300,000 benefited families and a budget of 367.3 million pesos. In 2000 the number of beneficiaries rose to $2,746,430$ families, while the yearly budget was at 9.518 billion pesos. In 2002 , when its name changed to Oportunidades, it covered 4.24 million benefited families and had a budget of 17 billion pesos. In 2005 it reached 5 million families and spent 32 billion pesos (Hevia 2007). The reference value of Mexican currency in 2007 was 10.5 pesos per US dollar.

3 An energy subsidy consists of cash aid for the families aimed in principle to the payment of electricity and gas bills. Each family is paid MXN\$170 (US\$15.5) as food aid, while

\section{References}

Adato, Michael (2004) 'Programas de Transferencias Monetarias Condicionadas Focalizadas. Beneficios y Costos Sociales' ['Targeted Conditional Cash Transfer Programmes: Social Benefits and Costs'], in J. Boltvinik and A. Damián (eds) La Pobreza en México y el Mundo. Realidades y Desafíos [Poverty in Mexico and Around the World: Reality and Challenges], Mexico: Gobierno del Estado de Tamaulipas/Siglo XXI: 348-63

Cornelius, Wayne; Graig, Ann and Fox, Jonathan (eds) (1994) Transforming State-Society Relations in Mexico: The National Solidarity Strategy, San Diego: Centre for US-Mexican Studies, University of San Diego: 357 achieve efficient mechanisms of participation and accountability in programmes of conditional cash transfers.

scholarships vary from MXN\$115 (US\$10.5) for children in the third year of primary school (no aid is granted for the first two years) to MXN\$730 (US\$66.4) for female students in the third year of high school. In addition, each adult member of the benefited families is granted MXN\$250 (US\$22.7). The maximum amount an individual family can receive in scholarship is $\mathrm{MXN} \$ 1,045$ (US\$95) for basic education and MXN\$1,775 (US\$161.4) for higher levels (Oportunidades 2006). Exchange rate $M X N \$ 10.5=U S \$ 1$.

4 The system for citizen complaints and suggestions reported 1,003 allegations of proselytism in the period 2003-6, 586 of which (58.4\%) referred to municipal liaisons/authorities and CPC members (Oportunidades 2007)

5 Another investigation (Hevia 2007) takes into analysis the incapacity of the system of citizen complaints to solve 'hardcore' faults related to practices of abuse of authority: money extortion, forced community labour, bad treatment, proselytism, etc.

6 An investigation into the effectiveness of the system of citizen complaints revealed that only 25 per cent of the 31 allegations of abuses of power had the support of local authorities or organisations (Hevia 2007).

7 The original idea was suggested by Yuriko Takahashi.

Dagnino, Evelina; Olvera, Alberto and Panfichi, Aldo (eds) (2006) 'Introducción, Para Otra Lectura de la Disputa por la Construcción Democrática en América Latina' ['Introduction: Towards Other Understanding About the Dispute for Constructing Democracy in Latin America], in La Disputa por la Construcción Democrática en América Latina [The Dispute for Constructing Democracy in Latin America], Mexico: FCE/CIESAS/UV

Fox, Jonathan (1992) The Politics of Food in Mexico. State Power and Social Mobilization, Ithaca: Cornell University Press

González de la Rocha, Mercedes and Escobar Latapi, Agustín (2002) Resultados de la Evaluación 
Cualitativa Basal del Programa de Educación, Salud y Alimentación (PROGRESA) [Education, Healthcare and Food Programme Qualitative Evaluation Findings], September-December, Mexico: CIESAS-Occidente Gurza Lavalle, Adrián (2003) 'Sem Pena nem Glória.

O Debate Sobre a Sociedade Civil nos anos 1990' ['No Sorrows, Neither Glory: Civil Society Debate During the Nineties'], Novos Estudos, CEBRAP 66: 91-109

Hevia de la Jara, Felipe (2007) 'Contraloría Social en el Programa Oportunidades: Análisis Desde la Optica de Interfaz Socioestatal', in Contraloría y Participación Social en la Gestión Pública. XIX Concurso del CLAD. Ensayos Ganadores 2006, ['Public Oversight in Oportunidades Program. Analysis from State-Society Interfaces Approach', Public Oversight and Social Participation in Public Administration, Winners Papers', XIX CLAD Contest], Caracas: Centro Latinamericano de Administración para el Desarrollo (Latin American Centre for Development Administration, CLAD) Isunza Vera, Ernesto and Hevia de la Jara, Felipe (2006) 'Relaciones Sociedad Civil-Estado en México. Un Ensayo de Interpretación' ['Civil Society-State Relations: An Interpretation Essay'], Cuadernos Para la Democratización 4, Mexico: CIESAS/UV

Levy, Santiago and Rodríguez, Evelyne (2004) 'El Programa de Educación, Salud y Alimentación,
PROGRESA-Programa de Desarrollo Humano Oportunidades' ['Education, Healthcare and Food Program PROGRESA - Human Development Program Oportunidades'], in S. Levy (ed.) Ensayos Sobre Desarrollo Económico y Social de México [Essays on Mexican Economic and Social Development], Mexico: Fondo de Cultura Económica (FCE): 181-379

Olvera, Alberto J. (2001) 'Movimientos Sociales Prodemocráticos, Democratización y Esfera Pública en México: El Caso de Alianza Cívica' ['Pro-Democratic Social Movements, Democratization and Public Sphere in Mexico: Civic Alliance Case'], Cuadernos de la Sociedad Civil 6, Mexico: Universidad Veracruzana

Oportunidades (2007) Sistema de Registro, Control y Seguimiento de la Demanda Ciudadana [System of Registering, Control and Follow up of Citizen Petitions], MS Excel system database, Dirección General de Atención y Operación. Dirección de Atención Ciudadana y Contraloría Social

Oportunidades (2006) Acuerdo que Establece las Reglas de Operación del Programa de Desarrollo Humano Oportunidades para el Ejercicio Fiscal 2006 [Agreement for Establishing Operational Rules for the Human Development Program Oportunidades], Mexico: Coordinación Nacional Programa de Desarrollo Humano Oportunidades 